\title{
One-Year Results From Cryopreserved Mitral Allograft Transplantation Into the Tricuspid Position in a Sheep Experimental Model
}

\author{
A. MOKRACEK ${ }^{1,2^{*}}$, J. CANADYOVA ${ }^{2 *}$, Z. SIMUNKOVA ${ }^{1}$, R. FIALA $^{3}$, M. HMIRAK $^{3}$, \\ M. SULDA ${ }^{2}$, J. BURKERT ${ }^{3}$, J. TINTERA ${ }^{4}$, P. KOBYLKA $^{5}$, J. SPATENKA $^{3}$ \\ * These authors contributed equally to the results of the present study and both should be considered as the first authors.
}

${ }^{1}$ Center of Experimental Medicine, Institute for Clinical and Experimental Medicine, Prague, Czech Republic, ${ }^{2}$ Department of Cardiac Surgery, Regional Hospital, Ceske Budejovice, Czech Republic, ${ }^{3}$ Department of Transplantation and Tissue Banking and Department of Cardiovascular Surgery, University Hospital in Motol, Prague, Czech Republic, ${ }^{4}$ Department of Radiology, Institute of Clinical and Experimental Medicine, Prague, Czech Republic, ${ }^{5}$ Institute of Hematology and Blood Transfusion, Prague, Czech Republic

Received October 9, 2014

Accepted February 20, 2015

On-line June 5, 2015

\section{Summary}

Mitral allografts are still used only exceptionally in the mitral or tricuspid position. The main indication remains infectious endocarditis of atrioventricular valves for its flexibility and low risk of infection. The aim of our study was to evaluate 1-year results of mitral allografts transplantation into the tricuspid position in a sheep model. Mitral allografts were processed, cryopreserved, and transplanted into the tricuspid position anatomically (Group I - 11 animals) or antianatomically (Group II -8 animals). All survivors (4 from Group I, and 3 from Group II) were checked at 3,6 , and 12 months by echocardiography with the exception of one survivor from Group II (which was examinated only visually). Examination throughout follow-up included for mitral allograft regurgitation and annuli dilatation. At postmortem, the papillary muscles were healed and firmly anchored to the right ventricular wall in all subjects. Transventricular fixation of the papillary muscles with buttressed sutures was proven to be a stable, reproducible, and safe method for anchoring mitral allograft leaflets. There were no significant differences between the two implantation methods. Annulus support of mitral allografts might be very useful in this type of operation and could prevent annular dilatation.

\section{Key words}

Mitral allograft • Tricuspid valve replacement • Cryopreservation - Sheep experimental model

\section{Corresponding author}

A. Mokracek, Center of Experimental Medicine, Institute for Clinical and Experimental Medicine, Videnska 1958, Prague 4, 140 00, Czech Republic. E-mail: a.mokracek@seznam.cz

\section{Introduction}

Our sheep model of mitral allograft (MA) transplantation into the tricuspid position had been developed previously and early results published (Vojáček et al. 2006, Mokráček et al. 2008). The aim of this project was to evaluate 1-year results of MA transplantation into the tricuspid position, again in the sheep model. The experiment was focused on MA (neotricuspid valve) function (e.g. incidence of regurgitation - MAR), MA structural degeneration, and comparison of two surgical techniques for MA transplantation - anatomical (Group I) and antianatomical (Group II) - from the viewpoint of long-term follow-up. 


\section{Methods}

The experimental studies were performed according to the guidelines and practice established by the Institutional Committee for Animal Care and Use and in compliance with legislation of the Czech Republic. All animals were cared for in compliance with the European Convention on Animal Care. The experimental project was also approved by the Institutional Committee of Ethics.

The total experimental series includes 20 cadaveric donor operations on sheep at the age of 1 year, weight 23 to $36 \mathrm{~kg}$. Nineteen sheep, 1 year of age, weight $24-38 \mathrm{~kg}$, underwent transplantation.

The experimental protocol (sheep donor MA harvesting, processing and cryopreservation, MA tissue thawing, anesthesiology as well as surgical techniques) used was taken over from our previous experience (Vojáček et al. 2006, Mokráček et al. 2008, Špatenka et al. 1997a,b, Špatenka and Kobylka 2011).

\section{Surgery}

After proper anatomical rotation of the MA, both papillary muscles were anchored transmurally using polypropylene monofilament mattress sutures (4/0 Prolene, Johnson \& Johnson, New Brunswick, NJ, USA) and buttressed with Teflon pledgets into the free right ventricular wall. MA annulus was then sewn into the recipient's tricuspid annulus by continuous running suture with the same sewing material. In the area adjacent to the septum, sutures were inserted through the retained rim of the tricuspid valve septal leaflet in order to prevent injury to the atrioventricular node. Two modes of transplantation were used and are termed the anatomical and antianatomical techniques.

In Group I (anatomical MA position), the anterior leaflet of the graft faced the septum while the posterior leaflet faced the right ventricular free wall.

In Group II (antianatomical position), the anterior leaflet faced the right ventricular free wall and the posterior leaflet of the MA faced the septum (Vojáček et al. 2006). On the "beating heart", MA function was water tested before the right atriotomy was closed using a monofilament running suture. After weaning from extracorporeal circulation, decannulation, and hemodynamic stabilization, the right atrial and pulmonary artery pressures were measured and recorded again. Perioperative cardiac anatomy and function were checked by epicardial echocardiography (ECHO) while focusing on the anatomy and function of the MA in the tricuspid position. Annular diameter was measured during ventricular diastole. The movement of mitral allograft cusps was analyzed in a 2D mode across the entire cardiac cycle. Color Doppler as well as continuous wave and pulsed wave Doppler assessments of MA flow were performed, and an aim was to grade the severity of mitral regurgitation.

When the postoperative course was smooth, sheep were cared for at the experimental department premises for 1 week and then returned to the farm and kept separately.

Follow-up

All survivors received veterinary check-ups and control transthoracic ECHO examinations at 3, 6 and 12 months. MA (neotricuspid) regurgitation (MAR) was examined for and then quantified on a standard fourgrade scale (I-IV/IV). The MAs' annuli were measured as well (Table 1).

All 1-year survivors were anesthetized. MA function was estimated by transthoracic ECHO using VIVID 7 ultrasound devices (GE Medical Systems, Little Chalfont, UK) with $7 \mathrm{~S}$ and $5 \mathrm{~S}$ probes.

Finally, the sheep were euthanized using the same technique as for the donor animals and the hearts were explanted. The right atrium and right ventricle were opened in order to ensure easy access to the implanted MA and to facilitate its macroscopic examination from both sides (atrial as well as ventricular). Healing of reattached papillary muscles and integrity of MA chordae tendineae were carefully checked from the right ventricle, as well. As the last step, leaflet samples were taken for histological study. The sections were stained using hematoxylin and eosin as well as by blue trichrome.

\section{Statistical analysis}

MAR was not analyzed statistically. ANOVA for repeated measures was used to analyze annuli enlargement. Computing (calculations and graph processing) was performed using Prism6 for Mac OS X (GraphPad Software, Inc., San Diego, CA, USA).

\section{Results}

The tricuspid valve was replaced with MA in a total of 19 sheep. The MA was implanted with normal anatomical orientation in 11 sheep (Group I) and in antianatomical orientation in the remaining 8 animals (Group II). Ten animals died perioperatively within $24 \mathrm{~h}$, 7 of these due to respiratory failure and 3 due to massive bleeding and coagulopathy. 
Table 1. Perioperative, 3-6 month and one-year fllow up - MA (neotricuspid anulus) size and function on echocardiography.

\begin{tabular}{|c|c|c|c|c|c|c|c|}
\hline Group & Sheep & $\begin{array}{l}\text { Perioperative } \\
\text { findings } \\
\text { Annular size } \\
\text { (mm), } \\
\text { Preop/Postop }\end{array}$ & $\begin{array}{c}\text { Perioperative } \\
\text { findings Neotricuspid } \\
\text { valve (MA) Function } \\
\text { (TR I-IV/IV) } \\
\text { (Echocardiography) }\end{array}$ & $\begin{array}{c}\text { 3-6 months } \\
\text { Annulus } \\
\text { size (mm) }\end{array}$ & $\begin{array}{c}\text { 3-6 months } \\
\text { Neotricuspid valve } \\
\text { (MA) Function } \\
\text { (TR I-IV/IV) } \\
\text { (Echocardiography) }\end{array}$ & $\begin{array}{l}12 \text { months } \\
\text { Annulus } \\
\text { size }(\mathrm{mm})\end{array}$ & $\begin{array}{c}12 \text { months } \\
\text { Neotricuspid valve } \\
\text { (MA) Function } \\
\text { (TR I-IV/IV) } \\
\text { (Echocardiography) }\end{array}$ \\
\hline \multirow[t]{4}{*}{ I. } & No 1 & $21 / 21$ & Competent TR 0/IV & 21 & Competent TR 0/IV & 27 & TR I/IV \\
\hline & No 2 & $19 / 19$ & $\begin{array}{l}\text { Competent TR 0/IV, } \\
\text { „bulging““ }\end{array}$ & 20 & $\begin{array}{l}\text { Competent TR 0/IV } \\
\text { „bulging“ }\end{array}$ & 27 & $\begin{array}{l}\text { TR I-II/IV } \\
\text { „bulging““ }\end{array}$ \\
\hline & No 3 & $22 / 22$ & $\begin{array}{l}\text { TR I/IV, both cusps } \\
\text { prolapse }\end{array}$ & 33 & $\begin{array}{c}\mathrm{TR} \text { II/IV, both cusps } \\
\text { prolaps }\end{array}$ & 35 & $\begin{array}{l}\text { TR II/IV, both } \\
\text { cusps prolaps }\end{array}$ \\
\hline & No 4 & $22 / 26$ & Competent TR 0/IV & 28 & Competent TR 0/IV & 28 & \\
\hline \multirow[t]{3}{*}{ II. } & No 1 & $19 / 20$ & $\begin{array}{l}\text { Competent TR 0/IV, } \\
\text { both cusps prolapse }\end{array}$ & 27 & $\begin{array}{l}\text { TR I/IV, both cusps } \\
\text { prolaps }\end{array}$ & 31 & $\begin{array}{l}\text { TR I/IV, both cusps } \\
\text { prolaps }\end{array}$ \\
\hline & No 2 & $18 / 18$ & $\begin{array}{l}\text { Competent TR 0/IV, } \\
\text { susp. of partial } \\
\text { chordae rupture }\end{array}$ & 20 & $\begin{array}{c}\text { Competent TR 0/IV } \\
\text { susp. of partial } \\
\text { chordae rupture }\end{array}$ & 26 & $\begin{array}{l}\text { Competent TR 0/IV } \\
\text { susp. of partial } \\
\text { chordae rupture }\end{array}$ \\
\hline & No 3 & $20 / 21$ & Competent TR 0/IV & - & - & - & - \\
\hline
\end{tabular}

MA - mitral allograft, TR - tricuspid regurgitation, I-IV/IV - grade I to IV of four grade scale of TR.

Perioperative residual valve incompetence grades 0 -I/IV was detected in 18 experimental animals. In 1 sheep, the residual perioperative mitral insufficiency was graded II/IV due to rupture of the anterior leaflet suspension apparatus, and that sheep died in the early postoperative period. Five sheep from Group I and 4 from Group II with trivial (0-I/IV) postoperative regurgitation of the mitral allograft in the tricuspid position advanced to the next phase of the experiment. One sheep from each group died at 3 weeks and 4 months after the operation. The first of these (from Group I) died due to mycotic MA infection. The second (from Group II) died suddenly and no clear cause of death was found at autopsy.

Echocardiographic follow-up in Group I revealed trivial or up to grade I/IV neotricuspid regurgitation in 3 sheep. In 1 animal, neotricuspid insufficiency of grade II/IV was detected due to prolapse of both cusps, mainly of the anterior leaflet, without rupture of the chordae (Fig. 1).

In Group II, grade I/IV neotricuspid insufficiency was found in 2 sheep, while echocardiography was not technically feasible for the third (Fig. 1). Because of the small numbers, MAR was not analyzed statistically. All measurable echocardiography parameters proved comparable neotricuspid valve morphology and hemodynamics.

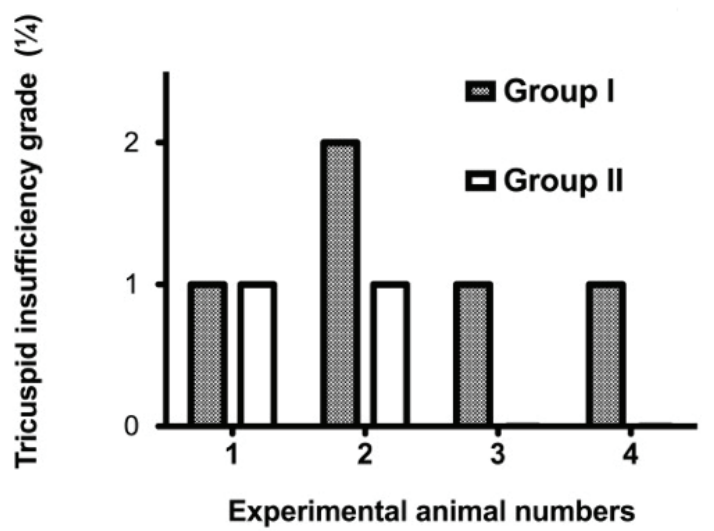

Fig. 1. Neotricuspid MA regurgitation in 12 months. Chi-square test $(1.283, p=0.7331)$.

The follow-up period was 1 year. Seven animals survived and were electively examined by twodimensional transthoracic echocardiography (Fig. 2, Table 1), four from Group I (anatomical transplantation) and three from Group II (antianatomical transplantation). 

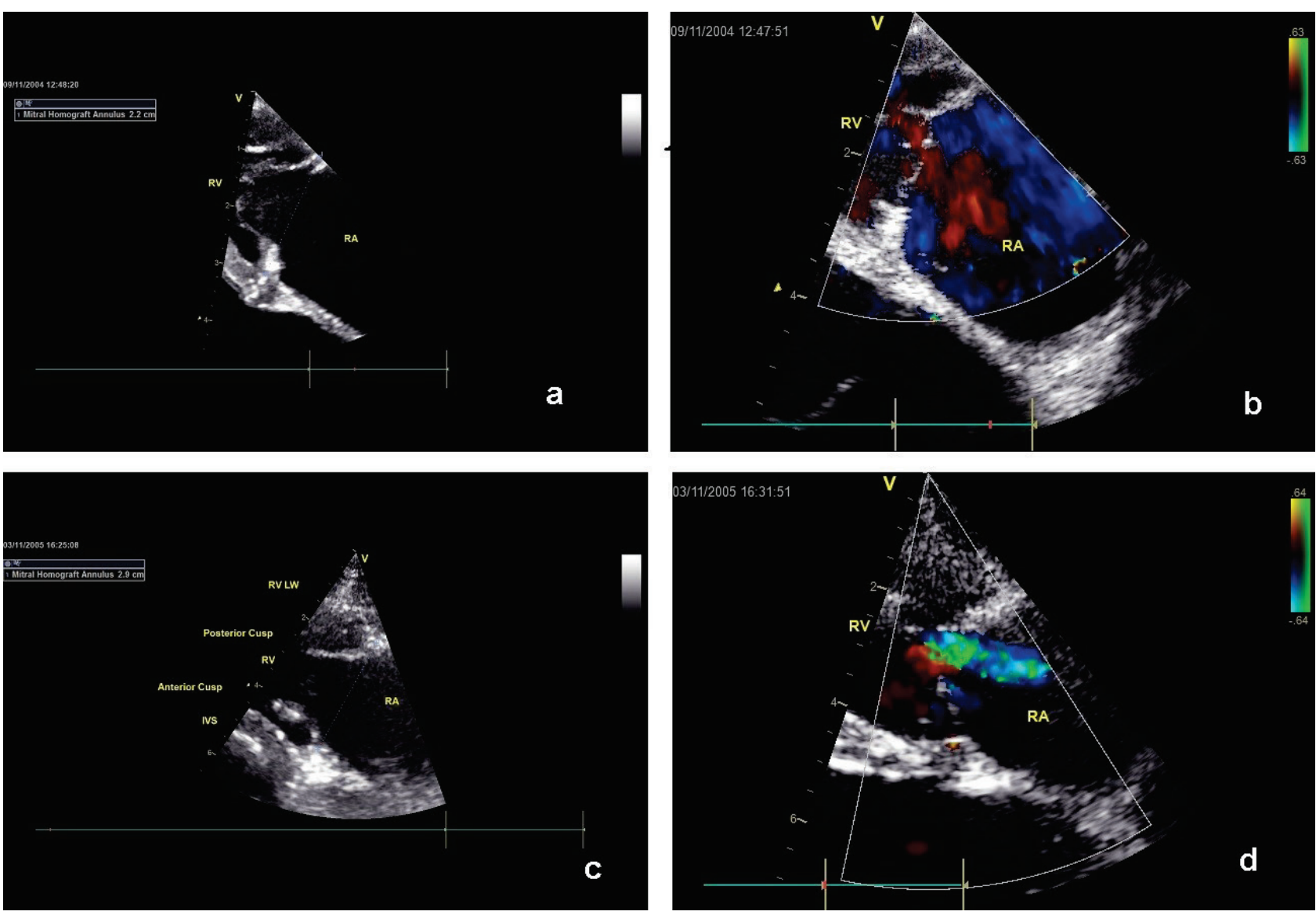

Fig. 2. a,b - post implantation neotricuspid annulus and MA (neotricuspid) regurgitation, $\mathbf{c}, \mathbf{d}$ - the annual echocardiography examination shows significant dilatation of neotricuspid annulus, but no significant MA (neotricuspid) regurgitation.

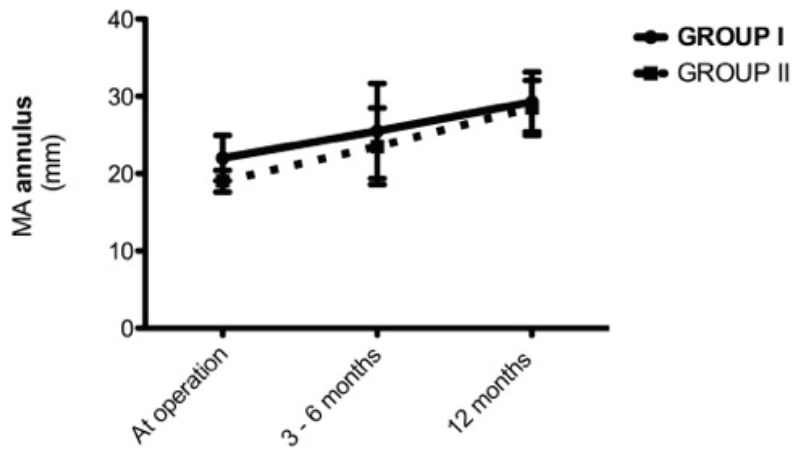

Fig. 3. MA annulus enlargement, comparing the postoperative measurements with follow-up at 3-6 and 12 months. Paired t-test, $p=0.986$, ns.

Tricuspid annular dilatation was shown to be reasonable in both groups (Fig. 3). MA dilation at 3 and 12 months postoperatively was significant in Group I ( $\mathrm{P}=0.03)$ but not significant in Group II $(\mathrm{P}=0.17)$, as determined by ANOVA for repeated measures.

Finally, the sheep were euthanized, the hearts were explanted, and final MA tests were performed. Macroscopic examination showed that the MAs were healed completely into the native tricuspid annuli as well as into the right ventricular wall (MA papillary muscles). Leaflets were whitish, appeared tough and less pliable, and were less pliable. No calcifications were found. In 2 hearts from Group I and 1 heart from Group II, small fenestrations were found in MA leaflets, albeit without any macroscopic inflammatory changes. Chordae remained firm, appeared fibrous and stiffer. From Group II, chordal rupture of the anterior leaflet was evident in 1 MA secondary. This probably was due to perioperative iatrogenic injury, and echocardiography follow-up suggested this had occurred in that animal from the very beginning. That morphological finding corresponded with MA regurgitation of I/IV at 1 year.

The mechanical quality of MA tissue was checked using a simple pulling test. All MA tissue remained firm enough in the cardiac surgeon's opinion.

Morphological leaflet tissue evaluation was done at the very end. This indicated that MA leaflets were denuded of endothelial cells. Irregular proliferation of fibrous tissue and elastic fibers in the thickened valve leaflet was apparent. Focal monocellular infiltration on the leaflet surface was documented (Fig. 4). 


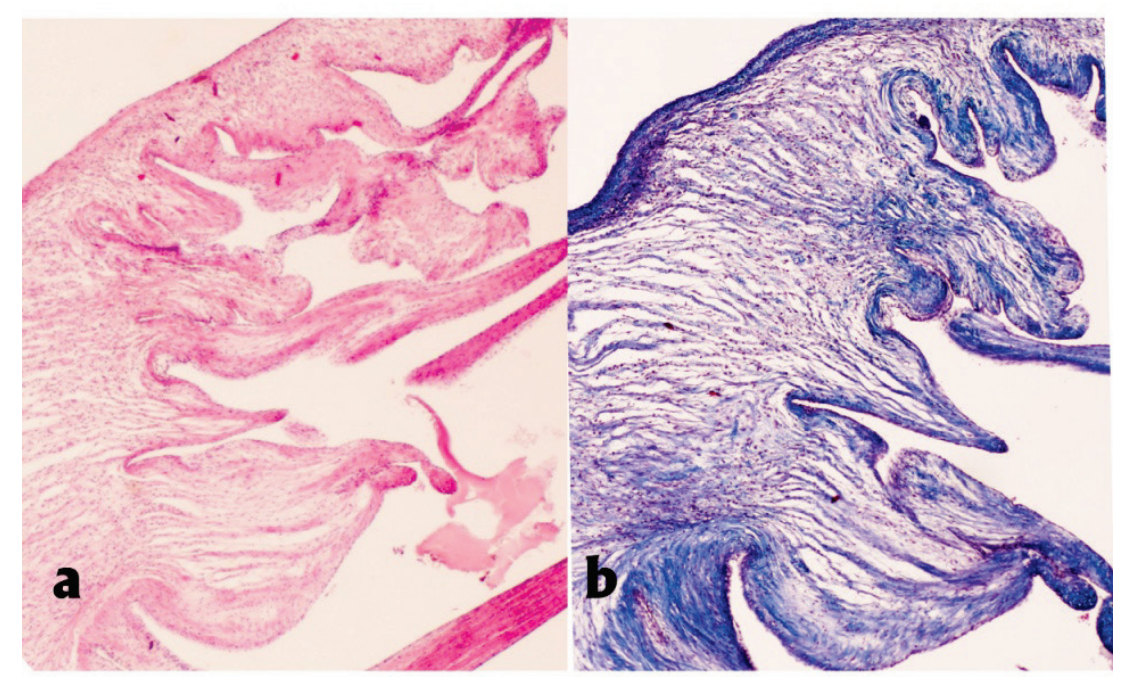

Fig. 4. $\mathbf{a}, \mathbf{b}$ - control animals mitral valve leaflets: cellulated valve, minimal admixture of elastic and fibrous fibers, c,d - mitral valve leaflets of the 12 months survivors: irregular proliferation of fibrous tissue and elastic fibers in the thickening valve. Focal monocellular infiltration on the surface. Left side: HE stain, right side: blue Trichrome stain. Magnification 40x.

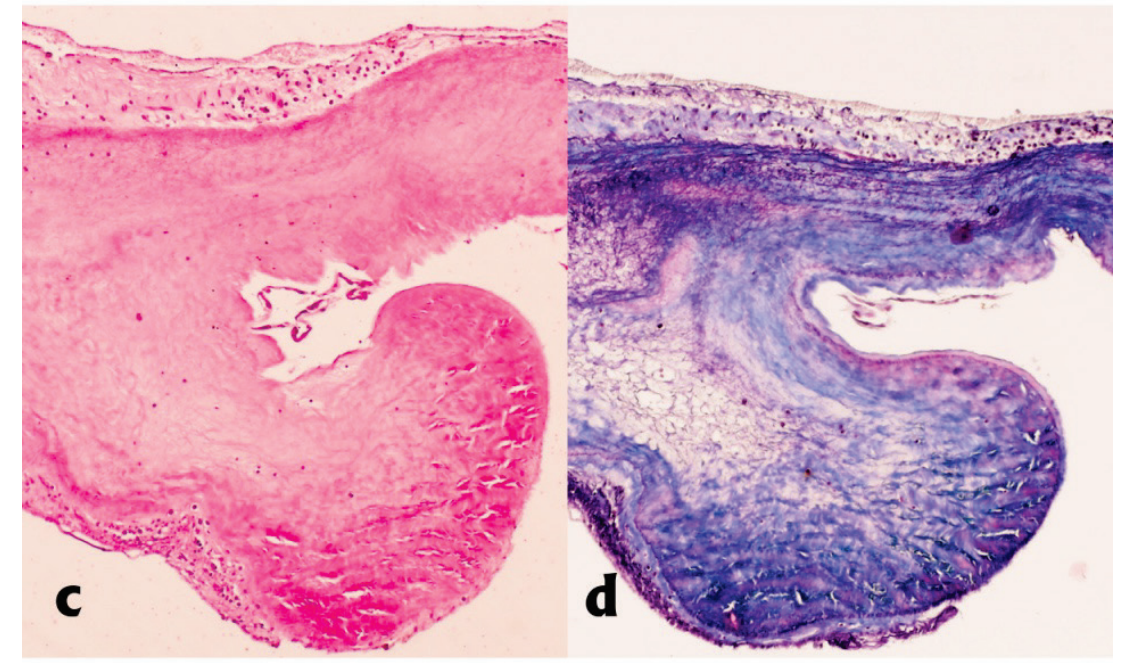

\section{Discussion}

Aortic allograft has been clinically used for more than 52 years (Ross 1962) and has been fully accepted by many surgeons as well as cardiologists. The history of MA transplantation into the mitral position is completely different. It was pioneered in a canine model (Rastelli et al. 1965, Vliet et al. 1965, Hubka et al. 1966). Clinical experience in limited series was also published (Cosgrove 1993, Pomar and Mestres 1993, Acar et al. 1994a, 1995, 1996, Miyaghishima et al. 2000).

The technique of MA transplantation using the original native valve attachment apparatus is particularly suitable for transplantation into the mitral valve. Nevertheless, there is a relatively high risk of dehiscence between native and allogenic papillary muscle (Sievers et al. 2004). Attempts to solve the problem by chemical fixation with glutaraldehyde were not successful. Biological tissue is never emphasized (Acar et al. 1994b). There is also a heightened risk of calcification and thereby of early degeneration (Tamura et al. 1995). Danger of dehiscence of subvalvular (supporting) apparatus constitutes the main limitation upon using MA. Ali et al. (2004) report a $5 \%$ reoperation rate due to MA failure within the first 3 months following MA transplantation. Due to its complexity and poor, unpredictable results at most centers, therefore, this method has never been widely used in clinical practice (Sievers et al. 1985). Only a few surgeons have documented very good results with MA transplantation into the mitral position (Acar et al. 1994b, 1996). An exceptional series of MA transplantations into mitral position with very good long-term results was published by a Paris group (Ali et al. 2004, Olivio et al. 2012). They evaluated the fates of 106 patients, wherein mean follow-up was 9.3 years and the longest survival was 17.8 years.

In contrast to MA utilization on the left side of the heart, quite promising results have been reported with MA transplantation into the tricuspid position (into the 
low-pressure system) (Cosgrove 1993, Pomar and Mestres 1993). Successful MA transplantation into the tricuspid position demands a good understanding of mitral valve anatomy and function, as well as detailed consideration of the mitral valve components' movements during the cardiac cycle.

Treatment of tricuspid valve infective endocarditis remains a challenge for cardiac surgeons and cardiologists. When valve repair is not feasible, then replacement with a commercially available mechanical or xenogeneic valve becomes necessary. An MA could provide another alternative. The method's main advantages are its absence of a synthetic material and no need for permanent anticoagulation. Another potential advantage of MA in the tricuspid position is to maintain at least partial mobility of the supporting apparatus. We could hypothesize that this might be important for longterm MA function (Hiro et al. 2004). Although some successful experience with replacement of infected tricuspid valves by MA transplantation into the tricuspid position has been documented (Katsumata and Westaby 1997, Couetil et al. 2002, Concha et al. 2003), MA implantation into the tricuspid position is currently rare (Concha et al. 2003, Couetil et al. 2002).

The preferred orientation of MA in the tricuspid position is subject to debate. Acar et al. (1994b) recommended anatomical orientation of the allograft with the septal leaflet facing to the septum and implantation of the mitral annuloplasty ring. This reduces tension and enlarges the coaptation line. In contrast, Pomar and Mestres (1993) used allografts in an antianatomical orientation, with the anterior (septal) leaflet opposite the free wall of the right ventricle. They also used native pericardium to reinforce the mitral annulus. For fixation of the papillary muscles allograft, they used the native recipient's muscles. This technique achieves good perioperative outcomes, but there is an absence of longterm monitoring data (Pomar and Mestres 1993). Anatomical or antianatomical orientation of the allograft in the recipient had the same functional result in our 1-year follow up. The hypothesis of better hemodynamic results from one or the other of these techniques was not confirmed. We believe the anatomical orientation (free wall cusp of allograft - posterior - in the free wall portion of the recipient's heart) is more physiological and it is our subjective preference.

A key aspect of MA transplantation concerns the anchoring technique used for fixing the mitral valve's hanging apparatus into the right ventricle. Fixation of the smallest possible remnant of papillary muscles with pledgets seems to be a good way to fix the allograft into the right ventricle.

To achieve reproducible results from MA transplantation into the tricuspid position, it appears crucial to standardize the surgical technique for papillary muscle fixation. It is also important to use the most appropriate types of papillary muscles (Cosgrove 1993). Acar et al. (1996) divided mitral allografts into 4 groups according to the anatomy of the supporting apparatus and papillary muscles. For use in the tricuspid position, only type I is generally suitable and type II just exceptionally (allografts with one or two papillary muscle heads, respectively). It is also suitable to use MAs larger than the native tricuspid annulus or to consider using a rigid or semi-rigid annuloplasty ring. MA behavior in the tricuspid position in the sheep model was described in detail by Bernal et al. (1998). For fixation of the papillary muscles, they used two techniques. The first technique fixed the papillary muscles of the MA to the recipient's right ventricular endocardium, and the second technique used transventricular fixation with pledgets. We adopted the second technique from Bernal et al. (1998) in our experiment. Given the possibility of intraoperative error, all procedures were performed by a single cardiac surgeon. We should note, too, that these experiments undoubtedly provide the best way to train in the tricky technique of MA transplantation into the tricuspid position for clinical use. Our group has previously published descriptions of MA harvesting and processing as well as detailed information concerning anesthesia, surgical technique, and echocardiography MA function assessment (Vojáček et al. 2006, Mokráček et al. 2008). These experiments and the presented series also have proven that the sheep model is reproducible. We have always stressed, however, that the fixation of the MA matches the anatomy of the MA rather than the native valve shape. Perioperative results were acceptable in all animals, and no significant perioperative incompetence on the allograft has been seen (Vojáček et al. 2006, Mokráček et al. 2008).

A case report from Dasarthan et al. (2010) describes promising results with using "homovital" MA harvested from the heart transplant recipient (i.e. "living donors"). Although this method was popularized for aortic allograft by Yacoub et al. (1995), contemporary Czech as well as EU legislation does not allow the use of a living donor's tissue grafts before an entire panel of obligatory donor data and investigation results is available. 
From the viewpoint of MA, the assessment of MAR was essential. Just a trace or up to I/IV MAR was proven. Statistical analysis was not feasible because of the small number of animals and investigations. No substantial MAR was detected despite annulus dilatation. This is probably a consequence of choosing an abundant size of MA in all animals.

The echocardiography examination at 3 and 12 months postoperatively revealed considerable annuli dilatation in all animals. On average, this was $144 \%$ of preoperative size (127-163\%). MA dilation at 3 and 12 months postoperatively was significant in Group I $(\mathrm{P}=0.03)$, while it was not significant in Group II $(\mathrm{P}=0.17)$. The validity of the statistical evaluation should be considered uncertain because of the small numbers.

There is no clear explanation for this inasmuch as the native annulus of the tricuspid valve was maintained during the surgery. Remodeling of the right ventricle geometry with its expansion due to changes in the subvalvular apparatus could probably be the cause. The question remains whether implantation of a stabilization system (mitral or tricuspid annuloplasty ring) would lead to better stabilization. The solution to this problem will be the aim of our further research. Although macroscopic examination as well as the simple pulling test for MA mechanical quality testing might not appear very scientific, these provide sufficient information to an experienced cardiac surgeon. In many operations on humans, this constitutes the final investigation and leads to the final decision concerning feasibility of the intervention. The mechanical properties of MA in a sheep model had been tested in our previous study and the surgeon's impression was always in agreement with the objective data from a traction machine. Mechanical MA testing was discussed extensively in that same article (Hlubocký et al. 2011).

\section{Conclusion}

MA implantation in the tricuspid position was technically feasible, the 1-year survival rate was acceptable, and 12-month follow-up results in a sheep experiment were satisfactory. There is no significant functional difference between implantation using either the anatomical or antianatomical techniques. With regard to intervention in humans, we will need to consider implantation of an annuloplasty ring. In our patients, the right atrium, tricuspid valve annulus, and right ventricle are usually dilated reasonably. This leads to impaired function of the right ventricle. The experimental results on a healthy sheep model should not therefore be overestimated.

\section{Conflict of Interest}

There is no conflict of interest.

\section{Acknowledgements}

The work was supported by Ministry of Health of the Czech Republic within the project for the development of research organization 00023001 (IKEM) - institutional support. The Center for Experimental Medicine (IKEM) received financial support from the European Commission within the Operational Program Prague Competitiveness; project "CEVKOON" (\#CZ).

\section{References}

ACAR C, IUNG B, CORMIER B, GRARE P, BERREBI A, D'ATTELLIS N, ACAR J, CARPENTIER AF: Double mitral homograft for recurent bacterial endocarditis of the mitral and tricuspid valves. J Heart Valve Dis 3: 470-472, 1994a.

ACAR C, FARGE A, RAMSHEYI A, CHACHQUES JC, MIHAILEANU S, GOUEZO R, GEROTA J, CARPENTIER AF: Mitral valve replacement using a cryopreserved mitral homograft. Ann Thorac Surg 5: 746-748, 1994 b.

ACAR C, GAER J, CHAUVAUD S, CARPENTIER AF: Technique of homograft replacement of the mitral valve. J Heart Valve Dis 4: 31-34, 1995.

ACAR CH, TOLAN M, BERREBI A, GEAR J, GOUEZO R, MARCHIX T, GEROTA J, CHAUVAUD S, FABIANI JN, DELOCHE A, CARPENTIER AF: Homograft replacement of the mitral valve. J Thorac Cardiovasc Surg 111: 367-380, 1996.

ALI M, IUNG B, LANSAC E, BRUNEVAL P, ACAR C: Homograft replacement of the mitral valve. Eight-year results. $J$ Thorac Cardiovasc Surg 128: 529-534, 2004.

ARBULU A, HOLMES RJ, ASFAW I: Surgical treatment of intractable right-sided infective endocarditis in drug addicts: 25 years experience. J Heart Valve Dis 2: 129-137, 1993. 
BERNAL JM, RABASA JM, CAGIGAS JC, VAL F, REVUELTA JM: Behavior of mitral allografts in the tricuspid position in the growing sheep model. Ann Thorac Surg 65: 326-330, 1998.

CONCHA M, ARANDA PJ, CASARES J, MERINO C, MUNOS I, ALADOS P, GONZALEZ JR, ROMO E: Mitral homograft in the tricuspid position, aortic homograft and mitral plasty in a drug addict with multiple valve endocarditis. $J$ Heart Valve Dis 12: 659-663, 2003.

COSGROVE D: Mitral homograft for tricuspid valve replacement. J Heart Valve Dis 2: 124, 1993.

COUETIL JPA, ARGYRIADIS PG, SHAFY A, COHEN A, BERREBI AJ, LOULMET DF, CHACHQUES JC, CARPENTIER AF: Partial replacement of the tricuspid valve by mitral homografts in acute endocarditis. Ann Thorac Surg 73: 1808-1812, 2002.

DASARTHAN C, VAIJYANATH P, CHERIAN KM: Replacement of the tricuspid valve with a homoviatal mitral homograft in infective endocarditis: a case report. Indian J Thorac Cardiovasc Surg 26: 207-209, 2010.

DEGANDT AA, WEBER PA, SABER HA, DURAN CMG: Mitral valve basal chordae: comparative anatomy and terminology. Ann Thorac Surg 84: 1250-1255, 2007.

HIRO ME, JOUAN J, PAGEL MR, LANSAC E, LIM KH, LIM HS, DURAN CMG: Sonometric study of the normal tricuspid valve anulus in sheep. J Heart Valve Dis 13: 452-460, 2004.

HLUBOCKÝ J, MOKRÁČEK A, NOVÁČEK V, VOJÁČEK J, BURKERT J, KOCHOVÁ P, KLEPÁČEK J, PEPPER J, ŠPATENKA J: Mechanical properties of mitral allografts are not reasonably infuenced by cryopreservation in sheep model. Physiol Res 60: 475-482, 2011.

HUBKA M, SISKA K, BROZMAN M, HOLEC V: Replacement of mitral and tricuspid valves by mitral homograft. J Thorac Cardiovasc Surg 51: 195-204, 1966.

KALOTERAKIS A, RIZOS I, GOUMAS G, FILIOTOU A, BARBETSEAS J, PAPATHANASIOU S, TOUTOUZAS P: Isolated native valve Candida endocarditis in non-drug-addicted patient. Case report and review of the literature. J Heart Valve Dis 12: 652-658, 2003.

KATSUMATA T, WESTABY S: Mitral homogtraft replacement of the tricuspid valve for endocarditis. Ann Thorac Surg 63: 1480-1482, 1997.

KUNZELMAN KS, COCHRAN RP, CHUONG CJ, RING WS, VERRIER ED, EBERHART RC: Finite element analysis of the mitral valve. J Heart Valve Dis 2: 326-340, 1993.

KUNZELMAN KS, REIMINK MS, COCHRAN RP: Annular dilatation increases stress in the mitral valve and delays coaptation: a finite element computer model. Cardiovasc Surg 5: 427-434, 1997.

MIYAGHISHIMA RT, BRUMWELL ML, JAMIESON WRE, MUNT BI: Tricuspid valve replacement using a cryopreserved mitral homograft. Surgical technique and initial results. J Heart Valve Dis 9: 805-809, 2000.

MOKRÁČEK A, HLUBOCKÝ J, BURKERT J, VOJÁČEK J, ŠULDA M, VAMBERA M, KURSA J, KROUPOVÁ V, KOBYLKA P, ŠPATENKA J: Transplantation of mitral allografts into the tricuspid position - a sheep experimental model. Acta Vet Brno 77: 89-95, 2008.

OLIVIO S, LALANDE S, NAPPI F, HAMMOUDI N, D'ALESSANDRO C, FOURET P, ACAR CH: Structural deterioration of the cryopreserved mitral homograft valve. J Thorac Cardiovasc Surg 144: 313-320, 2012.

POMAR JL, MESTRES CA: Tricuspid valve replacement using a mitral homograft. Surgical technique and initial results. J Heart Valve Dis 2: 125-128, 1993.

RASTELLI GC, BERGHUIS J, SWAN HJ: Evaluation of function of mitral valve after homotransplantations in the dog. J Thorac Cardiovasc Surg 49: 459-474, 1965.

SIEVERS HH, LANGE PE, YANKAH AC, VESSEL A, BERNHARD A: Allogenous transplantation of the mitral valve. An open question. Thorac Cardiovasc Surg 33: 227-229, 1985.

ŠPATENKA J, KOBYLKA P: Harvesting, processing and cryopreservation of allograft heart valves. Protocol of Allograft Heart Valve Cryobank. University Hospital Motol, Prague, Czech Republic, 2011.

ŠPATENKA J, KOSTELKA M, KOBYLKA P, HUCIN B, HONEK T, LOCHMAN O, HAJEK T, TLASKAL T, POVYSILOVA V, FISER B: Preparation, storage, transportation and use of heart valves for allotransplantation (in Czech). Rozhl Chir 76: 118-125, 1997a.

ŠPATENKA J, HONEK T, KOSTELKA M, HUCIN B, FISER B, HAJEK T, POVYSILOVA V, KOBYLKA P: Harvesting the heart for preparation of heart valve allografts (in Czech). Rozhl Chir 76: 113-117, 1997b. 
TAMURA T, JONES M, YAMADA I, FERRANS V: A comparison of failure modes of glutaraldehyde-treated vs. antibiotic preserved mitral valve allografts implanted in sheep. J Thorac Cardiovasc Surg 110: 224-238, 1995.

VANVLIET PD, TITUS JL, BERGHUIS J, ELLIS FH JR: Morphologic features of homotransplantated canine mitral valves. $J$ Thorac Cardiovas Surg 49: 504-510, 1965.

VOJACEK J, MOKRACEK, SPATENKA J, VAMBERA M, SULDA M, SETINA M, BURKERT J, PAVEL P, PEPPER J: Implantation of cryopreserved mitral allograft into the tricuspid positron in an experimental study in sheep: Technical aspects and immediate results evaluated by epicardial echocardiography. Zentralbl Chir 131: 511-516, 2006.

YACOUB M, RASMI NR, SUNDT TM, LUND O, BOYLAND E, RADLEY-SMITH R, KHAGANI A, MITCHELL A: Fourteen-year experience with homovital homografts for aortic valve replacement. $J$ Thorac Cardiovasc Surg 110: 186-193, 1995. 